JPPIPA, Vol.6 No.1 2021
Jurnal Penelitian Pendidikan IPA
http://journal.unesa.ac.id/index.php/jppipa

\title{
THE EFFECTIVENESS OF LEARNING VIDEO USAGE TO SUPPORT ONLINE LEARNING IN BASIC CHEMISTRY COURSES DURING THE COVID-19 PANDEMIC
}

Meida Wulan Sari ${ }^{1}$, Nurma Yunita Indriyanti ${ }^{2}$, Bayu Antrakusuma $^{3}$, Budi Utami ${ }^{4}$

1,2,3, ${ }^{4}$ Pendidikan IPA, Fakultas Keguruan dan Ilmu Pendidikan, Universitas Sebelas Maret, Indonesia

\begin{abstract}
This research aims to determine the effectiveness of learning video usage to support online learning in basic chemistry courses during the COVID-19 pandemic. This research was conducted at the FKIP UNS Undergraduate Science Education Study Program. The subjects in this research were 60 students from the $1^{\text {st }}$ semester who took basic chemistry courses. This research was conducted in the odd semester of the 2020 or 2021 academic year and was conducted online and utilized the SPADA platform for viewing learning videos. The data collection technique in this research used a questionnaire. The use of questionnaires aims to obtain an overview of the effectiveness of learning video. Data analysis used quantitative descriptive with a score for each question, from 1 to 5 . The results of the research showed that the use of learning video during the COVID-19 pandemic could support online learning, namely obtaining an effectiveness percentage of $84 \%$ with a very good category. Therefore, learning videos are effective in helping students understand the concepts that are being studied and motivating students to online learning.
\end{abstract}

Keywords: Online Learning, Learning Video, COVID-19

(C) 2021 Universitas Negeri Surabaya 


\section{INTRODUCTION}

Indonesia nowadays inevitably has to face the acceleration of the digital transformation of education triggered by the COVID-19 pandemic. The whole world in such a short time transformed conventional face-to-face learning patterns in schools into distance or online learning that relies heavily on technology. UNICEF, WHO, and IFRC in COVID-19 Prevention and Control in Schools (2020) said that when the rate of virus spread is accelerating, all activities carried out in schools must be stopped and in order for the education process to continue, learning activities can be carried out online using various media.

The COVID-19 pandemic has also caused three fundamental changes in global education (Tam and El Azar, 2020). First, changing the way millions of people are educated. Second, new solutions for education that can bring about muchneeded innovation. Third, the existence of a digital divide causes new shifts in educational approaches and can widen the gap. Hoskins (2013) mentions that it is not easy to do distance learning among students. Even though this learning is easier to do for adult students. In addition, this learning must be supported by appropriate classroom design and delivery methods so that online learning can encourage students to reflect on their beliefs, provide a comfortable environment to discuss various perspectives, guide them to explore, validate, and broaden new perspectives.

In Indonesia, online learning is regulated in a circular letter from the Ministry of Education and Culture of 2020 which includes three main points in online learning. First, the online learning presented must provide a meaningful learning experience. Second, online learning should focus on life skills education, for example regarding the COVID-19 pandemic so that students know how dangerous the disease is and how to prevent and treat it. Third, activities and assignments can vary between students, which means that assignments must be given according to their respective interests and conditions, including considering students' conditions at home, for example, related to internet access.

Online learning is defined as learning that teaches new knowledge using video, audio, images, text communication, software (Basilaia \& Kvavadze, 2020) and with the support of the internet network (Zhu \& Liu, 2020). Through online learning, new knowledge can be learned through website forums (Basilaia \& Kvavadze, 2020) and digital technology which is the embodiment of the industrial revolution 4.0 and is considered capable of supporting learning during the COVID-19 pandemic. Through online learning, learning is not limited by space and time. The interaction between lecturers and students can take place anytime and anywhere. Online learning is a distinct advantage for lecturers and students who can make students more active in constructing knowledge (Syarifudin, 2020).

But in reality, based on the results of research conducted by Pawicara and Conilie (2020), it shows that online learning during the COVID-19 pandemic has an impact on student learning boredom. This is known through indicators of emotional exhaustion, physical fatigue, cognitive fatigue, and loss of motivation. This is also reinforced by research conducted by Herdiana, Rudiana, and Supriatna (2021) showing that online lectures bring out student boredom in taking online lectures, this is partly due to internal factors originating from themselves such as not accustomed to learning with an online system, and external factors, such as the delivery of material by sometimes very boring and unattractive, and the absence of friends who can be directly invited to discuss lecture material.

During online learning, the most important things is the readiness of lecturers and students to interact online, given that changes to online learning indirectly affect student absorption (Dewi, 2020). Therefore, during online learning, the lecturer must ensure that learning is fun, full of meaning, awakens creativity, critical power, and is able to enable students to learn independently. Lecturers often take advantage of several digital platforms that can support online learning including whatsApp groups, google facilities (google classroom, google form, google meet), and zoom cloud meetings. But the use of video conferencing technology such as google meet and zoom cloud is often disrupted by unstable internet networks and the use of whatsapp groups and google classrooms requires learning materials that can be studied independently. Therefore, the foresight of the lecturers in choosing learning media that can support online learning is something that deserves attention. The learning media chosen must be able to motivate students to continue to be enthusiastic about learning.

Online learning that utilizes learning media has several advantages, namely: (1) increasing student interest in the learning material being studied so that it can foster high learning motivation, (2) delivery of learning material is very clear so that students can understand and master learning well, (3) teaching methods become more varied because they use learning media, (4) student interactions with the surrounding environment during the learning process will increase and of course this happens on their own initiative (G., M. Tahir \& Darwis, 2021). According to Milman (2015) the 
use of digital technology can be used during the learning process, even though lecturers and students are in different places, they can still abble to carry out the learning process. Therefore, learning video media is considered more effective in online learning because it is one type of audiovisual media to support online learning.

According to Cheppy Riyana (2007) learning video media is media that presents audio and visuals containing good learning messages containing concepts, principles, procedures, knowledge application theory to help understanding a learning material. The learning video media as teaching materials aims to: (1) clarify and facilitate the delivery of learning materials so that they are not too verbalistic, (2) overcome the limitations of time, space, and sensory power of lecturers and students, and (3) can be used appropriately and variedly. In order for learning video to increase user motivation and effectiveness, the development of learning video must pay attention to their characteristics. The characteristics of the learning video are: clarity of message, stand alone, friendly or familiar with the wearer, content representation, media visualization, high resolution quality, can be used classically or individually. The advantages of using video media according to Daryanto (2010) include: when watching learning videos we can adjust the size of the video display as needed, learning videos are teaching materials that are rich in information and straightforward in their delivery because they are able to reach students directly, and videos add a new dimension to learning.

Learning video media is very suitable for subject matter because it can describe a certain process, a demonstration plot, a concept, or describe something, especially in chemistry subject matter (Cheppy Riyana, 2007). Studying material in chemistry is not enough just to read books and memorize formulas, what's more, chemistry is relatively abstract (Ariaji, Nasirsah, \& Siregar, 2020). Therefore, the use of learning video media in basic chemistry course materials is expected to be able to support online learning during the COVID-19 pandemic.

Based on this background description, the problem formulation of this research is "How is the Effectiveness of Using Learning Videos to Support Online Learning of Basic Chemistry Courses in the COVID-19 Pandemic Period".

\section{METHOD}

\section{Research Design}

This research design namely Analysis, Design, Development and Implementation, and Evaluation. It is shown in figure 1 .

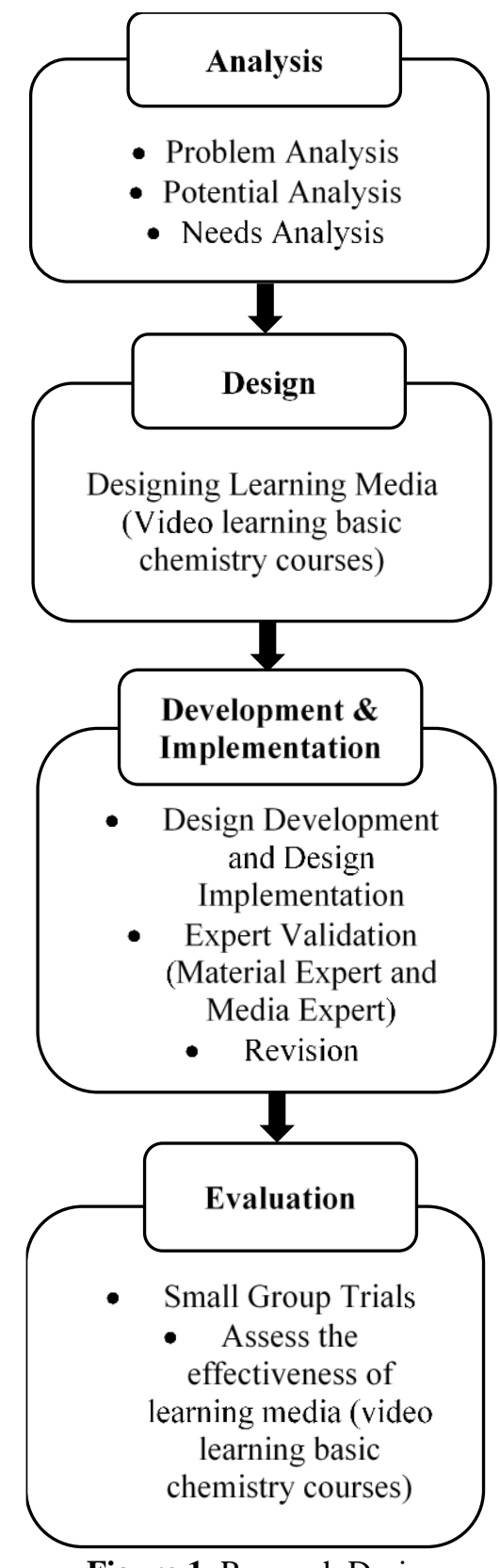

Figure 1. Research Design

\section{Research Objectives}

The subjects in this research were 60 students from the $1^{\text {st }}$ semester of the FKIP UNS Undergraduate Science Education Study Program who took basic chemistry courses. This research was conducted in the odd semester of the 2020 or 2021 academic year. This research was conducted online and utilized the SPADA platform for viewing learning videos. 


\section{Data Collection Techniques}

The data collection technique used a questionnaire. The use of questionnaires aims to obtain an overview of the effectiveness of the learning video. The questionnaire consists of 16 questions. Data analysis used quantitative descriptive with a score for each question, from 1 to 5 . Then, the results were analyzed using the following formula:

$$
\begin{aligned}
& \text { Percentage of effectiveness } \\
& =\frac{\text { Score obtained }}{\text { maximum number of scores }} \times 100 \%
\end{aligned}
$$

Percentage values are interpreted by the criteria in Table 1.

Table 1. Interpretation of the Effectiveness of Learning Video

\begin{tabular}{cc}
\hline Percentage (\%) & Criteria \\
\hline $0-20$ & Very Less \\
$21-50$ & Less \\
$51-60$ & Enough \\
$61-80$ & Good \\
$81-100$ & Very Good \\
\hline & (Riduwan, 2013)
\end{tabular}

\section{RESULTS AND DISCUSSION}

The learning video before being given to students has been validated first. Validation is needed to analyze the quality of the learning video. Validation was carried out by two validators, namely media experts and material experts. The aspects assessed include content validation (format, language, content) and construct validation. The average score of the validation results of the learning video is assessed from the content aspect ranging from 3.5 to 4 with valid to very valid criteria. This shows that the format (audio and visual display), language, and content of the material in the video can support online learning. The average score of the validation results of the learning video was assessed from the constructed aspect, namely obtaining a score of 4 with very valid criteria. This shows that the material in the video is relevant to CPMK, is grouped into logical parts, and the tasks are given in the order of the material.

The learning video in this research is used to study basic chemistry courses on the material of equilibrium shifts and the factors that influence it. This learning video has a duration of 22 minutes consisting of introduction (apperception and motivation), content (material), practice questions, and closing. The content section is equipped with animation and experimental video.

Chemistry is a complex concept and abstract therefore according to (Coll, 2008; Jansoon, Coll, \& Somsook, 2009) in learning requires three levels representation includes, at the macroscopic level, submicroscopic, and symbolic.

\begin{tabular}{|c|c|c|c|c|c|c|}
\hline \multirow{2}{*}{ Numb. } & \multirow{2}{*}{ Question } & \multicolumn{5}{|c|}{$\begin{array}{l}\text { Student Responses } \\
(\%)\end{array}$} \\
\hline & & 1 & 2 & 3 & 4 & 5 \\
\hline 1 & $\begin{array}{l}\text { The phenomenon of equilibrium shifting can be clearly } \\
\text { observed through the experimental video shown }\end{array}$ & $0 \%$ & $0 \%$ & $10 \%$ & $53,3 \%$ & $36,7 \%$ \\
\hline 2 & $\begin{array}{l}\text { The sub-microscopic phenomenon of equilibrium shift } \\
\text { can be clearly observed through the animation shown }\end{array}$ & $0 \%$ & $0 \%$ & $13,3 \%$ & $58,3 \%$ & $28,3 \%$ \\
\hline 3 & $\begin{array}{l}\text { The symbols used in the video further clarify the } \\
\text { concept being studied }\end{array}$ & $0 \%$ & $0 \%$ & $10 \%$ & $60 \%$ & $30 \%$ \\
\hline 4 & The experimental video display can be seen clearly & $0 \%$ & $0 \%$ & $5 \%$ & $38,3 \%$ & $56,7 \%$ \\
\hline 5 & The animation view can be seen clearly & $5 \%$ & $5 \%$ & $8,3 \%$ & $26,7 \%$ & $55 \%$ \\
\hline 6 & The text on the video can be read clearly & $0 \%$ & $0 \%$ & $3,3 \%$ & $33,3 \%$ & $63,3 \%$ \\
\hline 7 & $\begin{array}{l}\text { The audio explanation sentence (narration) on the video } \\
\text { can be heard clearly }\end{array}$ & $0 \%$ & $0 \%$ & $6,7 \%$ & $50 \%$ & $43,3 \%$ \\
\hline 8 & The audio speed (narration) of the video & $0 \%$ & $5 \%$ & $46,7 \%$ & $43,3 \%$ & $5 \%$ \\
\hline 9 & Display speed of each video & $0 \%$ & $5 \%$ & $53,3 \%$ & $35 \%$ & $6,7 \%$ \\
\hline 10 & $\begin{array}{l}\text { I feel better when I see a video accompanied by an } \\
\text { audio explanation (narration) }\end{array}$ & $0 \%$ & $0 \%$ & $11,7 \%$ & $51,7 \%$ & $36,7 \%$ \\
\hline 11 & The video display is very interesting & $0 \%$ & $0 \%$ & $11,7 \%$ & $41,7 \%$ & $46,7 \%$ \\
\hline 12 & The use of video is very helpful in learning & $0 \%$ & $0 \%$ & $3,3 \%$ & $45 \%$ & $51,7 \%$ \\
\hline 13 & $\begin{array}{l}\text { This video can motivate me to learn about shifting } \\
\text { equilibrium and the factors that influence it }\end{array}$ & $0 \%$ & $0 \%$ & $11,7 \%$ & $48,3 \%$ & $40 \%$ \\
\hline 14 & $\begin{array}{l}\text { An animated display on the video can explain the } \\
\text { phenomenon of equilibrium shifting }\end{array}$ & $0 \%$ & $0 \%$ & $8,3 \%$ & $61,7 \%$ & $30 \%$ \\
\hline 15 & $\begin{array}{l}\text { The connection between the experimental video, } \\
\text { animation, and narration in the form of audio makes it } \\
\text { easier for me to understand the concepts that are being } \\
\text { studied }\end{array}$ & $0 \%$ & $0 \%$ & $11,7 \%$ & $46,7 \%$ & $41,7 \%$ \\
\hline 16 & Lecture material is conveyed through learning video & $0 \%$ & $3,3 \%$ & $16,7 \%$ & $53,3 \%$ & $26,7 \%$ \\
\hline
\end{tabular}

Table 2. Student responses related to use of learning video 
More information:

5 : Very Clear/Very Fast/Very Agree/Very Understood

4: Clear/Fast/Agree/Understand

3 : Less clear/less fast/less agree/less understanding

2: Unclear/Not Fast/Disagree/Don't Understand

1 : Very Unclear/Very Unresponsive/Very Disagreeable/Very Uncertain

Macroscopic representation is a concrete level, where at this level students observe phenomena that occur, either through experiments conducted or phenomena that occur in everyday life. Properties of macroscopic representation is real and can be directly observed. Example: color, shape, temperature, and others. Based on the results of student responses, $53.3 \%$ stated that the equilibrium shift phenomenon can be clearly observed through the experimental video shown. Submicroscopic representation is an abstract level that explains macroscopic phenomena. Closely submicroscopic relation to the underlying theoretical model explanation of the dynamics of the particle level (atoms, molecules, and ions). Mode of representation on level it can express starting from which simple, for example using technology computer, using words, picture two dimensional, three-dimensional images both still and moving (animation) or simulation. Based on the results of student responses, 58.3\% stated that the submicroscopic phenomenon of equilibrium shifts can be clearly observed through the animation shown. The symbolic (or icon) level of representation is the representation to identify identities (e.g. substances involved in chemical reactions) with use qualitative symbolic language and quantitative, such as chemical formulas, diagrams, drawings, equations, stoichiometry, and calculations mathematical. Based on the results of student responses, $60 \%$ stated that the symbols used in the video further clarified the concept being studied. This shows that through learning video media students can study chemistry using three levels of representation includes, at the macroscopic level, submicroscopic, and symbolic. so that student motivation and understanding during online learning increases.

Based on the results of the questionnaire that had been filled in, it showed that in general the use of learning video according to students was effectively implemented, namely obtaining an effectiveness percentage of $84 \%$ in the very good category. The data can be seen in Table 2 .

Based on Table 2 shows that $51.7 \%$ of students gave a score of 5 out of 5 which stated that the use of video was very helpful in learning. This shows that the majority of students agree that learning videos help in understanding learning materials, especially materials that require visualization of practicum activities such as basic chemistry courses. This is reinforced by research conducted by Ridha, Firman, Desyandri (2021) which shows that the use of learning video media is preferred by students because it can motivate and help them study at home. This is because learning video has advantages, including: (1) being able to explain the real state of a process, phenomenon, or event, (2) being able to enrich the explanation when integrated with other media, (3) students can repeat learning material that is not clear, (4) very helpful in teaching material that focuses on activities psychomotor such as practical activities, (5) faster and more effective in conveying messages than text media, and (6) able to clearly show simulations or procedural steps or methods (Munir, 2013).

\section{CONCLUSION AND RECOMMENDATION \\ CONCLUSION}

The conclusion of this research shows that the use of learning video during the COVID-19 pandemic can support online learning, namely obtaining an effectiveness percentage of $84 \%$ with a very good category. Learning videos can make it easier for students to understand the concepts that are being studied and motivate them to online learning.

\section{RECOMMENDATION}

The recommendation given by the researcher is that the researcher hopes to develop other learning media that can support online learning, so that it can improve understanding, creativity, motivation, and student learning outcomes.

\section{REFERENCES}

Ariaji, R., Nasirsah, \& Siregar, S. A. 2020. Pengembangan Video Pembelajaran Kimia SMA/MA Menggunakan Camtasia Studio 8. EKSAKTA: Jurnal Penelitian dan Pembelajaran MIPA, Vol. 5 No. 1, pp/ 5564.

Basilaia, G., \& Kvavadze, D. 2020. Transition to online education in schools during a SARS-CoV-2 coronavirus (COVID-19) pandemic in Georgia. Pedagogical Research, Vol. 5 No. 4, pp. 1-9.

BPS. Potret Pendidikan Statistik Pendidikan Indonesia 2019. Jakarta: Badan Pusat Statistik. Diunduh pada Tanggal 5 Mei 2021,

dari https://www.bps.go.id/publication/2019/11/ 29/1deb588ef5fdbfba3343bb51/potretpendidikan-statistik-pendidikan-indonesia2019.html.

Cheppy Riyana. 2007. Pedoman Pengembangan Media Video. Jakarta: P3AI UPI. 
Coll, R. K. 2008. Chemistry learners' preferred mental models for chemical bonding. Journal of Turkish Science Education (TUSED), Vol. 5 No. 1. Retrieved from http://www.tused.org/index.php/tused/ho me

Daryanto. 2010. Media Pembelajaran, Peranannya Sangat Penting Dalam Mencapai Tujuan Pembelajaran. Yogyakarta: Gava Media.

Dewi, W. A. F. (2020). Dampak COVID-19 terhadap Implementasi Pembelajaran Daring di Sekolah. EDUKATIF Jurnal Ilmu Pendidikan, Vol. 2 No. 1, pp. 55-61.

G., M. Tahir \& Darwis, M. 2021. Belajar Mandiri dan Pembelajaran Berbasis Daring di Perguruan Tinggi. JETCLC, Vol. 1 No. 1, pp. 28-34.

Herdiana, D., Rudiana, R., \& Supriatna. 2021. Kejenuhan Mahasiswa dalam Mengikuti Perkuliahan Daring dan Strategi Penanggulangannya. Edunesia: Jurnal Ilmiah Pendidikan, Vo. 2 No. 1, pp. 293307.

Hoskins, B. J. 2013. Is Distance Learning Transformational?.The Journal of Continuing Higher Education, Vol. 61 No 1, pp. 62-63, DOI: 10.1080/07377363.2013.759488.

Jansoon, N., Coll, R. K., \& Somsook, E. (2009). Understanding mental models of dilution in Thai students. International Journal of Environmental and Science Education, Vol. 4 No. 2, pp. 147-168.

Majid, Abdul. 2011. Perencanaan Pembelajaran. Bandung: Remaja Rosadakarya.

Munir. 2013. Multimedia: Konsep dan Aplikasi dalam Pendidikan. Bandung: Alfabeta.

Pawicara, R. \& Conilie, M. 2020. Analisis Pembelajaran Daring terhadap Kejenuhan Belajar Mahasiswa Tadris Biologi IAIN
Jember di Tengah Pandemi COVOD 19. ALVEOLI: Jurnal Pendidikan Biologi, Vol. 1 No. 1, pp. 29-38.

Ridha, M., Firman, \& Desyandri. 2021. Efektifitas Penggunaan Media Video pada Pembelajaran Tematik Terpadu di Sekolah Dasar Saat Pandemi Covid-19. Jurnal Pendidikan Tambusai, Vol. 5 No. 1, pp. 154-162.

Riduwan. 2013. Skala Pengukuran Variabelvariabel Penelitian. Bandung: Alfa Beta.

Syarifudin, A. S. 2020. Implementasi Pembelajaran Daring untuk Meningkatkan Pendidikan Mutu Pendidikan sebagai Dampak Diterapkannya Sosial Distancing. METALINGUA Jurnal Pendidikan Bahasa dan Sastra Indonesia, Vol. 5 No. 1, pp. 3134.

Tam, Gloria \& El-Azar, Diana. 2020. 3 ways the coronavirus pandemic could reshape education. Diunduh pada Tanggal $5 \mathrm{Mei}$ 2021, dari Sumber: https://www.weforum.org/agenda/2020/03/ 3-ways-coronavirus-is-reshapingeducation-and-what-changes-might-behere-to-stay/.

UNICEF, IRC, \& WHO. 2020. Key Messages and Actions for COVID-19 Prevention and Control in Schools. Diunduh pada Tanggal 2 Mei 2021, dari https://www.who.int/docs/defaultsource/coronaviruse/key-messages-andactions-for-covid-19-prevention-andcontrol-in-schools-march2020.pdf?sfvrsn=baf81d52 4.

Zhu, X., \& Liu, J. (2020). Education in and After Covid-19: Immediate Responses and LongTerm Visions. Postdigital Science and Education, doi: 10.1007/s42438-02000126-3. 